\title{
Roles of MEK/ERK Pathway in Vascular and Renal Tubular Actions of Angiotensin II
}

\author{
George Seki ${ }^{a^{*}}$, Hideomi Yamada ${ }^{\mathrm{a}}$, Yuehong Li ${ }^{\mathrm{a}, \mathrm{b}}$, Shoko Horita ${ }^{\mathrm{a}}$, Nobukazu Ishizaka ${ }^{\mathrm{a}}$, \\ Kazuhiko Koike and Toshiro Fujita ${ }^{\mathrm{a}}$
}

${ }^{a}$ Department of Internal Medicine, Faculty of Medicine, The University of Tokyo; ${ }^{b}$ Department of Nephrology, People's Hospital, Peking University, Japan

\begin{abstract}
Chronic kidney disease (CKD) is now widely recognized as a significant risk factor for cardiovascular disease (CVD). Chronic angiotensin II (Ang II) stimulation facilitates tissue hyperplasia, hypertrophy, and inflammation, and the current medical strategy for CKD is primarily based on the suppression of rein-angiotensin system. Since Ang II induces hypertension through both vasoconstriction and sodium retention, the understanding of vascular and renal actions of Ang II is essential for the better management of CKD and CVD. Ang II is coupled to a variety of intracellular signaling pathways depending on cell types, and Ang II type 1 receptor $\left(\mathrm{AT}_{1}\right)$ is thought to be responsible for most, if not all, of the cardiovascular effects of Ang II. Recent studies have suggested that the MEK/ERK pathway plays an important role in Ang II-mediated vascular smooth muscle contraction, where cytosolic phospholipase $\mathrm{A}_{2}\left(\mathrm{CPLA}_{2}\right) / \mathrm{P} 450$ pathway has a positive feedback effect. Interestingly, the MEK/ERK pathway has been also shown to mediate the stimulatory effect of Ang II on renal proximal transport. However, the $\mathrm{CPLA}_{2} / \mathrm{P} 450$ pathway has a negative feedback effect on the Ang II-mediated ERK activation in renal proximal tubules. Thus, arachidonic acid metabolites seem to play quite contrasting roles in the Ang IImediated ERK activation in vascular and renal tissues. This article will be focused on the roles of MEK/ERK pathway in vascular and renal tubular actions of Ang II.
\end{abstract}

Keywords: Angiotensin II, MEK/ERK pathway, $\mathrm{CPLA}_{2}$, arachidonic acid, P450.

\section{INTRODUCTION}

The renin-angiotensin system (RAS) is fundamental for the regulation of cardiovascular system. In particular, angiotensin II (Ang II) is a key hormone in regulation of blood pressure. Although Ang II affects the function of virtually all organs [1], the kidney plays an essential role in the Ang IIinduced hypertension $[2,3]$. In addition to the vascular effects, Ang II has direct effects on renal tubular functions. Ang II acts on sodium and bicarbonate absorption from proximal tubules, and this process is thought to have a significant impact on body fluid and sodium homeostasis $[4,5]$. While acute stimulation with Ang II affects vasoconstriction and solute homeostasis, chronic stimulation facilitates hyperplasia and hypertrophy of vascular smooth muscle cells (VSMCs) [6, 7].

Recently, the involvement of extracellular signal regulated kinase (ERK) pathway in Ang II-mediated vasoconstriction has been recognized [8-11]. The recent study has shown that the ERK pathway is also involved in the Ang IImediated stimulation of sodium absorption from renal proximal tubules [12]. However, Ang II seems to utilize quite different signaling mechanisms to activate ERK in VSMCs and renal tubules. Since ERK is one of the key fac-

*Address correspondence to this author at the Department of Internal Medicine, Faculty of Medicine, The University of Tokyo, 7-3-1 Hongo, Bunkyoku, Tokyo 113-0033, Japan; Tel: +81-3-3815-5411 ext. 33004; Fax: +81-35800-8806; E-mail: georgeseki-tky@umin.ac.jp tors connecting the acute and chronic effects of Ang II, this review will focus on the roles of ERK pathway in vascular and renal Ang II actions.

\section{CHRONIC Ang II EFFECTS}

Ang II is known to activate mitogen-activated protein kinases (MAPKs), such as ERK1/2, JNK and p38MAPK. These pathways may be involved in chronic Ang II actions such as cell differentiation, proliferation, hypertrophy, or migration [1, 13-15]. In addition, Ang II is a potent activator of oxidative stress and oxidant signaling, and reactive oxygen species (ROS) are at least partially responsible for the pleiotrophic effects of Ang II [16-18]. In VSMCs, Ang II activates membrane $\mathrm{NAD}(\mathrm{P}) \mathrm{H}$ oxidase to produce ROS, which facilitate vascular inflammation $[18,19]$. In endothelial cells, the Ang II-induced ROS production has been implicated in endothelial dysfunction [16]. The intracellular ROS have been shown to activate transcriptional factor NF$\kappa \mathrm{B}$, which may result in increased expression of VCAM-1, an important factor in endothelial adhesion [20]. Several modes of cross-talk may exist between MAPKs-dependent and ROS-dependent signaling pathways [1].

Chronic activation of RAS in vivo is thought to promote proinflammatory and atherogenic responses through multiple mechanisms, which would eventually result in tissue damages including myocardial infarction, heart failure, stroke, and kidney disease $[1,21]$. For example, RAS is considered 
to play pathogenic roles through multiple mechanisms in chronic kidney disease (CKD), a condition associated with increased risk for cardiovascular disease (CVD) [22]. A recent clinical study indeed showed that patients with CKD have a high prevalence of insulin resistance, metabolic syndrome, and chronic inflammation, and that the treatment with an angiotensin receptor blocker (ARB) olmesartan significantly improves insulin resistance as well as inflammation markers in these patients [23].

\section{EFFECTS OF RAS INHIBITION IN CKD}

The inhibition of RAS is one of the main therapeutic options in CKD treatment. Previous clinical trials have established the beneficial effects of both angiotensin-converting enzyme (ACE) inhibitors and ARBs in preventing or delaying end-organ damage. Thus, ACE inhibition consistently improved CVD morbidity and mortality rates in patients with heart failure and left ventricular dysfunction [24]. In addition, ACE-inhibitor treatment with captopril significantly reduced loss of renal function in patients with type 1 diabetes [25]. ARB treatment with losartan was also associated with significant reduction in the progression of nephropathy in patients with type 2 diabetes [26]. In view of these beneficial results, a notion becomes wildly accepted that ACE inhibitors and ARBs have tissue protective effects beyond their antihypertensive effects. However, a recent meta-analysis did not support this notion; the beneficial effects of these drugs were attributed only to the reduction of blood pressure [27]. Although this conclusion has drawn much attention and/or criticism, the full understanding of molecular mechanism underlying multiple Ang II actions is obviously indispensable for the establishment of more effective therapeutic strategies for CKD.

\section{Ang II RECEPTORS AND G-PROTEIN COUPLED PATHWAYS}

Angiotensin II (Ang II) receptors can be pharmacologically divided into two major subtypes, type $1\left(\mathrm{AT}_{1}\right)$ and type $2\left(\mathrm{AT}_{2}\right)$ receptors. $\mathrm{AT}_{1}$ belongs to the seven-membrane superfamily of $\mathrm{G}$-protein coupled receptors. In rodents, $\mathrm{AT}_{1}$ receptors are further divided into $\mathrm{AT}_{1 \mathrm{~A}}$ and $\mathrm{AT}_{1 \mathrm{~B}}$ receptors $[28,29]$. While $\mathrm{AT}_{1 \mathrm{~A}}$ and $\mathrm{AT}_{1 \mathrm{~B}}$ cannot be pharmacologically discriminated [30,31], $\mathrm{AT}_{1 \mathrm{~A}}$ may be more important than $\mathrm{AT}_{1 \mathrm{~B}}$ in blood pressure control [32]. While most of the physiological effects of Ang II are mediated by $\mathrm{AT}_{1}$ receptors $[28,29], \mathrm{AT}_{2}$ may also be involved in the regulation of cardiovascular system [33]. In some cases, $\mathrm{AT}_{2}$ may antagonize the $\mathrm{AT}_{1}$-mediated signaling via serine/threonine phophatases [34]. However, the exact role of $\mathrm{AT}_{2}$ in Ang IImediated biological actions has remained still unclear.

$\mathrm{AT}_{1}$-mediated acute vasoconstriction is mediated by Gprotein coupled signaling pathways. Upon stimulation, $\mathrm{AT}_{1}$ couples to G-protein complexes, which activate downstream effectors such as phospholipase C (PLC) and phospholipase $\mathrm{A}_{2}\left(\mathrm{PLA}_{2}\right)[1,35,36]$. Activation of PLC produces inositol1,4,5-triphophate $\left(\mathrm{IP}_{3}\right)$ and diacylglycerol (DAG). $\mathrm{IP}_{3}$ increases cell $\mathrm{Ca}^{2+}$ concentrations through binding to and opening of its receptor on sarcoplasmic reticulum. $\mathrm{Ca}^{2+}$ binds to calmodulin, and triggers actin-myosin interaction, causing smooth muscle cell contraction $[1,37]$. In addition to this classical pathway, the ERK pathway may also participate in the Ang II-induced cell $\mathrm{Ca}^{2+}$ increase in VSMCs from human resistance arteries [8]. On the other hand, DAG activates PKC, which not only activates the $\mathrm{Na}^{+} / \mathrm{H}^{+}$exchanger [38], but also transmits the signal to the Raf/mitogen-activated protein kinase (MEK)/ERK pathway.

\section{ERK PATHWAY IN Ang II ACTIONS ON VASCULAR TONE}

A MEK inhibitor PD98059 was shown to significantly attenuate the Ang II-induced increase in blood pressure, indicating that the ERK pathway is involved in the Ang IImediated acute vasoconstriction [8-11]. The molecular mechanism underlying the ERK-mediated vascular contraction is not completely understood, but phosphorylation of either myosin light chain regulatory subunit or caldesmon may be involved $[39,40]$. These targets are considered to increase contraction through modulation of the actin-myosin interaction [41].

There are several proposed models, which link G-proteincoupled receptors to the ERK cascade [1, 15, 42]. They include Ras-dependent ERK activation via transactivation of receptor tyrosine kinases such as the epidermal growth factor receptor (EGFR) and platelet derived growth factor receptor (PDGFR), or Ras-independent ERK activation via PKC. While EGFR transactivation is thought to be mediated either by release of heparin-binding EGF (HB-EGF) or by cytosolic tyrosine kinase Src, the PKC-dependent ERK activation converges the EGF-dependent signaling at the level of Raf. For example, Eguchi et al. showed that the rapid Ang IIinduced ERK activation in VSMCs is dependent on cell $\mathrm{Ca}^{2+}$ increase as well as Ras and tyrosine kinase activities [43].

In endogenous conditions, however, the transactivation pathway may be less dominant as postulated, whereas pathways involving PKC isoforms may play a more important role as assumed so far [15]. Interestingly, a recent study by Escano et al. revealed that Ang II activates ERK through distinct mechanisms in different types of VSMCs [11]. They showed that Ang II activates ERK through the transactivation mechanism in VSMCs from thoracic aorta. In VSMCs from renal microvascular, however, Ang II seems to activate ERK through a unique mechanism, which is not dependent on EGFR or PDGFR, but still dependent on Src.

\section{REGULATION OF RENAL PROXIMAL TRANSPORT BY Ang II}

Ang II is one of the most effective activators of renal proximal transport. There are two distinct features in the Ang II actions on renal proximal tubules. Firstly, proximal tubular fluid contains markedly high concentrations of Ang II, which cannot be explained by simple spill over of systemic circulation [44]. In fact, proximal tubular cells have all the components to locally generate Ang II, which, after being secreted into proximal tubular lumen, may exert paracrine/autocrine effects $[45,46]$. Secondly, Ang II regulates renal proximal transport in a biphasic manner; stimulation by low (picomolar to nanomolar) concentrations of Ang II and inhibition by high (nanomolar to micromolar) concentrations of Ang II [4, 5]. 
Traditionally, the stimulatory effect of Ang II has been attributed to the activation of PKC and/or the decrease in the intracellular cAMP level, while the inhibitory effect of Ang II has been attributed to the activation of phospholipase $A_{2}$ $\left(\mathrm{PLA}_{2}\right)$ and the subsequent release of arachidonic acid [4749]. Although conflicting data have been reported as to the identity of receptor subtype(s) mediating this unique mode of regulation $[50,51]$, the data obtained from Ang II type 1 receptor $\left(\mathrm{AT}_{1}\right)$-deficient mice have clearly shown that $\mathrm{AT}_{1}$ mediates both stimulatory and inhibitory effects of Ang II $[52,53]$. This conclusion is consistent with a generally accepted view that the expression of $\mathrm{AT}_{2}$ is very high in fetal kidney, but rapidly declines soon after birth, and is very low or undetectable in adult kidney $[54,55]$.

A majority of bicarbonate absorption (or proton secretion) in renal proximal tubules is coupled to sodium absorption. This process is accomplished by the coordinated operation of the apical $\mathrm{Na}^{+} / \mathrm{H}^{+}$exchanger NHE3 and the basolateral electrogenic $\mathrm{Na}^{+}-\mathrm{HCO}_{3}{ }^{-}$cotransporter $\mathrm{NBC} 1[56,57]$. Previous studies showed that Ang II stimulates the activities of both NHE3 and NBC1 $[52,58,59]$.

\section{ERK PATHWAY IN Ang II ACTIONS ON RENAL PROXIMAL TRANSPORT}

In opossum kidney (OK) cells, acidosis was shown to activate the NHE3 activity through Src and MEK/ERK pathways [60]. In OK cells, Ang II was shown to activate the NBC1 activity through the nonreceptor tyrosine kinase proline-rich tyrosine kinase 2 ( $\mathrm{Pyk} 2) / \mathrm{Src}$ family kinase coupling, which might be indispensable for the downstream activation of ERK [61]. By contrast, Douglas and colleagues, based on the data obtained from cultured rabbit proximal tubular cells, presented the evidence that the extracellular signal-regulated kinase (ERK) pathway mediates the inhibitory effect of Ang II [50,62]. In view of these conflicting results, the role of ERK pathway in Ang II-effects on renal transport had not been definitely established.

To clarify this issue, our group examined the role of ERK pathway in Ang II-mediated biphasic regulation of NBC1 activity in isolated mouse proximal tubules. The ARB olmesartan abolished both the stimulation by $10^{-10} \mathrm{~mol} / \mathrm{L}$ Ang II and the inhibition by $10^{-6} \mathrm{~mol} / \mathrm{L}$ Ang II, consistent with the $\mathrm{AT}_{1}$-mediatd biphasic regulation of $\mathrm{NBC1}$. On the other hand, the MEK inhibitor PD9805 abolished only the stimulatory effect of Ang II, leaving the inhibitory effect of Ang II unaffected. These results indicate that the ERK pathway mediates only the stimulatory effect of Ang II in intact proximal tubules [12]. Further analysis showed that the inhibitory effect of Ang II is independent of the ERK pathway, but dependent on the group IVA cytosolic PLA 2 (cPLA2 $\alpha$ ) activity. These observations indicate that Ang II activates ERK and cPLA2 $\alpha$ with different concentration dependency via $\mathrm{AT}_{1}$, and that the balance between ERK and cPLA2 $\alpha$ activities determines the final responses to Ang II in intact proximal tubules [12]. It remains to be determined whether the Pyk2/Src coupling, as shown in OK cells [61], is also responsible for the Ang II-induced ERK activation in intact proximal tubules.

\section{ROLES OF ARACHIDONIC ACID METABOLITES IN Ang II ACTIONS}

Ang II activates $\mathrm{CPLA}_{2}$ in both VSMCs and renal proximal tubules. $\mathrm{CPLA}_{2}$ preferentially catalyzes the hydrolysis of sn-2 position of glycerophospholipids to release arachidonic acid, which in turn is metabolized to prostaglandins by the cyclooxgenase pathway and to leukotriens by the 5lipoxygenase pathway [63]. Renal proximal tubules, on the other hand, abundantly express the cytochrome P450 epoxygenase [64], and the arachidonic acid metabolites through this pathway, mainly 5,6- epoxyeicosatrienoic acid (EET), are involved in the inhibitory effect of Ang II [12, 48, 49, 65]. Interestingly, arachidonic acid metabolites seem to play quite contrasting roles in the Ang II-induced ERK activation in VSMCs and renal proximal tubules.

In VSMCs, Muthalif and colleagues identified a key role of hydroxyeicosatetraenoic acid (HETE) in the Ang IImediated ERK activation [10]. They showed that the stimulation of $\mathrm{cPLA}_{2}$ by Ang II or norepinephrine facilitates arachidonic acid release. P450 metabolites of arachidonic acid, such as 12,15-HETE or 20-HETE, activate ERK by the Ras/Raf/MEK pathway. Activation of MEK/ERK in turn amplifies $\mathrm{cPLA}_{2}$ activity and further releases arachidonic acid. Thus, the $\mathrm{CPLA}_{2} / \mathrm{P} 450 / \mathrm{HETE}$ pathway and the ERK cascade constitute a positive feedback loop in VSMCs (Fig. (1)). This model is also consistent with a vasoconstrictive effect of 20-HETE, which has been attributed to the inhibitory effect on $\mathrm{K}^{+}$channel activities [66-68].

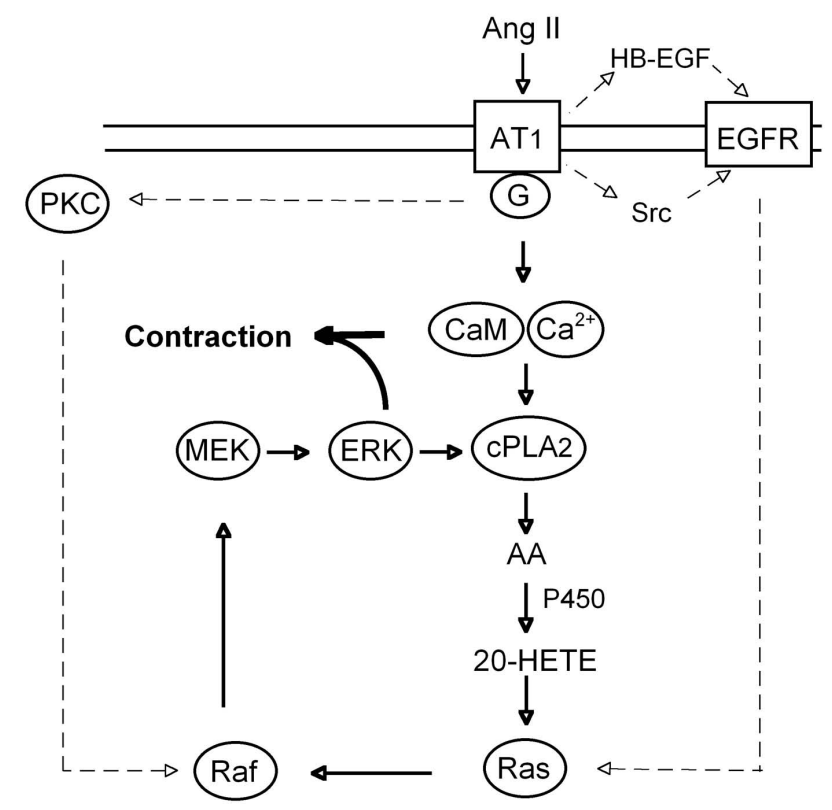

Fig. (1). The role of MEK/ERK pathway in Ang II actions on vascular smooth muscle contraction. In this model, $\mathrm{Ca}^{2+}$ ions bind to calmodulin $(\mathrm{CaM})$, which not only facilitates contraction but also activates $\mathrm{cPLA}_{2}$. Arachidonic acid (AA), released by cPLA $_{2}$, is then metabolized by P450, and metabolites such as 20 HETE activate ERK by the Ras/Raf/MEK pathway through a positive feedback mechanism. While EGFR transactivation either through HB-EGF or Src may activate the Ras/Raf/MEK pathway, PKC may activate the Raf/MEK pathway. The ERK activation also contributes to contraction. $\mathrm{G}, \mathrm{G}$ protein 
By sharp contrast, the $\mathrm{CPLA}_{2} \alpha / \mathrm{P} 450$ pathway might work to prevent the ERK activation by Ang II in proximal tubules. Thus, $10^{-10} \mathrm{~mol} / \mathrm{L}$ Ang II significantly activated ERK, but high concentrations of Ang II $\left(>10^{-8} \mathrm{~mol} / \mathrm{L}\right)$ failed to activate ERK in kidney cortex obtained from wild-type mice. When the $\mathrm{CPLA}_{2} \alpha$ activity was abrogated by pharmacological means or genetic knockout, however, high concentrations of Ang II were able to activate ERK [12]. These observations indicate that the $\mathrm{CPLA}_{2} \alpha / \mathrm{P} 450 / \mathrm{EET}$ pathway rather works as a negative feedback loop on the ERK cascade in intact renal proximal tubules (Fig. (2)). This finding is quite surprising, because P450 metabolites are reported to activate ERK in a number of different types of cells such as endothelial cells, arterial smooth muscle cells, glomerular mesangial cells, and renal tubular epithelial cells $[69,70]$. However, the further analysis in intact proximal tubules revealed that Ang II failed to activate ERK in the presence of arachidonic acid or 5,6EET, supporting the negative effect of arachidonic acid metabolites on the ERK pathway ( $\mathrm{Li}, \mathrm{Y}$ and Seki G, unpublished observation). Moreover, the negative effect of EET on ERK activation is consistent with a protective role of EET in Ang II-induced renal injury [71].

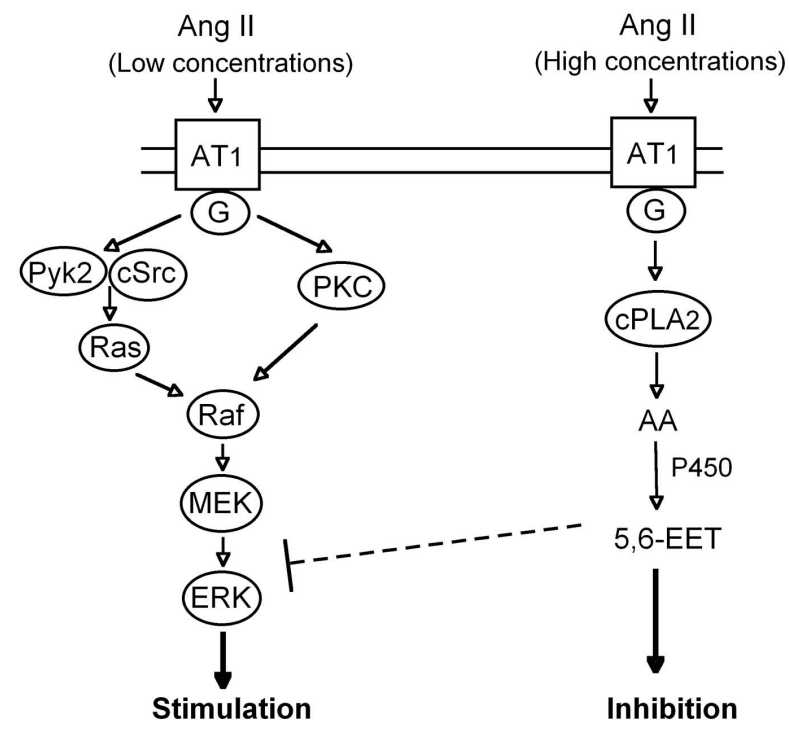

Fig. (2). The role of MEK/ERK pathway in Ang II actions on renal proximal transport.

In this model, $\mathrm{AT}_{1}$ mediates both stimulatory and inhibitory effects of Ang II. The activation of Raf/MEK/ERK pathway, which is mediated by either Pyk $2 / \mathrm{cSrc}$ coupling or PKC, is responsible for the stimulatory effect of Ang II. On the other hand, the activation of $\mathrm{cPLA}_{2}$ by higher concentrations of Ang II is responsible for the inhibitory effect. Furthermore, arachidonic acid metabolites such as 5,6-EET may have a negative feedback effect on the MEK/ERK pathway.

At present the exact molecular mechanism underlying the contrasting effects of $\mathrm{cPLA}_{2} / \mathrm{P} 450$ pathway on the ERK cascade in vascular smooth muscle cells and renal proximal tubules remains unknown. The P450-eicosanoids are known to activate a variety of intracellular signaling pathways, which may be mediated by a putative cell surface receptor or direct intracellular interaction [70]. It is tempting to speculate, however, that renal proximal tubules may have to de- velop the unique mechanism to attenuate excessive actions of Ang II. Indeed, in situ proximal tubular fluid is reported to contain markedly high concentrations of Ang II [44], and uncontrolled Ang II actions may result in unwarranted sequences such as cell hypertrophy or cell damage $[14,71]$.

\section{OTHER SIGNALING PATHWAYS}

Recently other signaling pathway mediating the Ang IIinduced ERK activation in vascular tissues have been reported. For example, Min et al. reported that aldosterone and Ang II synergistically increase the ERK activation in VSMCs [72]. Chai et al. reported that aldosterone potentiates the vasoconstrictor effect of Ang II in coronary arteries [73]. Interestingly, both nongenomic and genomic actions of aldosterone seem to be involved in these interactions, which support the benefit of combination therapy with blockade of aldosterone and $\mathrm{AT}_{1}$ receptors in the treatment of hypertension and heart-failure [74].

Another interesting observation is the involvement of small $\mathrm{G}$ protein Rho in vascular effects of Ang II. Rho has been shown to participate in the formation of focal adhesions and actin stress fibers, as well as in mediating the redistribution of cytoskeletal components [75]. In cardiac myocytes, Aikawa et al. reported that Rho-kinase is involved in the stretch-induced ERK activation, but not in the Ang IIinduced ERK activation [76]. In mesenteric arteries, on the other hand, Matrougui et al. reported that Rho-kinase is involved in the ERK activation and the contraction induced by Ang II [77], suggesting that Rho might be a future therapeutic target.

\section{CONCLUDING REMARKS}

This review, which focuses on the mechanism of ERK activation by Ang II, reveals that the $\mathrm{cPLA}_{2} / \mathrm{P} 450$ pathway has the positive feedback effect in vascular smooth muscle, but has the negative feedback effect in renal proximal tubules. Interestingly, several lines of evidence suggest that the alteration of P450 activities is associated with hypertension in both rodents and human [78-80]. For example, several members of EET are known to have antihypertensive properties, which have been attributed to the effect on vascular tone $[70,81]$. However, the negative effect on ERK cascade in renal proximal tubules could be also involved in the antihypertensive properties of EET, since the ERK activation is coupled to the stimulation of proximal transport [12]. For the better understanding of multiple cardiovascular consequences of RAS activation, future studies are warranted aiming to clarify the different effects of arachidonic acid metabolites on ERK-dependent pathways in vascular and renal tissues.

\section{ACKNOWLEDGEMENTS}

This study was in part supported by grant from the Ministry of Education, Culture, Sports, Science and Technology of Japan.

\section{REFERENCES}

[1] Mehta PK, Griendling KK. Angiotensin II cell signaling: physiological and pathological effects in the cardiovascular system. Am J Physiol Cell Physiol 2007; 292: C82-C97. 
[2] Crowley SD, Gurley SB, Oliverio MI, et al. Distinct roles for the kidney and systemic tissues in blood pressure regulation by the renin-angiotensin system. J Clin Invest 2005; 115: 1092-9.

[3] Crowley SD, Gurley SB, Herrera MJ, et al. Angiotensin II causes hypertension and cardiac hypertrophy through its receptors in the kidney. Proc Natl Acad Sci U S A 2006; 103: 17985-90.

[4] Harris PJ, Young JA. Dose-dependent stimulation and inhibition of proximal tubular sodium reabsorption by angiotensin II in the rat kidney. Pflugers Arch 1977; 367: 295-7.

[5] Schuster VL, Kokko JP, Jacobson HR. Angiotensin II directly stimulates sodium transport in rabbit proximal convoluted tubules. J Clin Invest 1984; 73: 507-15.

[6] Geisterfer AA, Peach MJ, Owens GK. Angiotensin II induces hypertrophy, not hyperplasia, of cultured rat aortic smooth muscle cells. Circ Res 1988; 62: 749-56.

[7] Xi XP, Graf K, Goetze S, Fleck E, Hsueh WA, Law RE. Central role of the MAPK pathway in ang II-mediated DNA synthesis and migration in rat vascular smooth muscle cells. Arterioscler Thromb Vasc Biol 1999; 19: 73-82.

[8] Touyz RM, He G, Deng LY, Schiffrin EL. Role of extracellular signal-regulated kinases in angiotensin II-stimulated contraction of smooth muscle cells from human resistance arteries. Circulation 1999; 99: 392-9.

[9] Touyz RM, El Mabrouk M, He G, Wu XH, Schiffrin EL. Mitogenactivated protein/extracellular signal-regulated kinase inhibition attenuates angiotensin II-mediated signaling and contraction in spontaneously hypertensive rat vascular smooth muscle cells. Circ Res 1999; 84: 505-15.

[10] Muthalif MM, Benter IF, Karzoun N, et al. 20-Hydroxyeicosatetraenoic acid mediates calcium/calmodulin-dependent protein kinase II-induced mitogen-activated protein kinase activation in vascular smooth muscle cells. Proc Natl Acad Sci USA 1998; 95: 12701-6.

[11] Escano CS, Jr., Keever LB, Gutweiler AA, Andresen BT. Angiotensin II activates extracellular signal-regulated kinase independently of receptor tyrosine kinases in renal smooth muscle cells: implications for blood pressure regulation. J Pharmacol Exp Ther 2008; 324: 34-42.

[12] Li Y, Yamada H, Kita Y, et al. Roles of ERK and cPLA2 in the angiotensin II-mediated biphasic regulation of $\mathrm{Na}^{+}-\mathrm{HCO}_{3}^{-}$transport. J Am Soc Nephrol 2008; 19: 252-9.

[13] Sugden PH, Clerk A. Regulation of the ERK subgroup of MAP kinase cascades through $G$ protein-coupled receptors. Cell Signal 1997; 9: 337-351.

[14] Hannken T, Schroeder R, Zahner G, Stahl RA, Wolf G. Reactive oxygen species stimulate p44/42 mitogen-activated protein kinase and induce $\mathrm{p} 27(\mathrm{Kip} 1)$ : role in angiotensin II-mediated hypertrophy of proximal tubular cells. J Am Soc Nephrol 2000; 11: 1387-97.

[15] Liebmann C. Regulation of MAP kinase activity by peptide receptor signalling pathway: paradigms of multiplicity. Cell Signal 2001; 13: 777-85.

[16] Rajagopalan S, Kurz S, Munzel T, et al. Angiotensin II-mediated hypertension in the rat increases vascular superoxide production via membrane NADH/NADPH oxidase activation. Contribution to alterations of vasomotor tone. J Clin Invest 1996; 97: 1916-23.

[17] Ushio-Fukai M, Alexander RW, Akers M, et al. Reactive oxygen species mediate the activation of Akt/protein kinase B by angiotensin II in vascular smooth muscle cells. J Biol Chem 1999; 274 : 22699-704.

[18] Griendling KK, Sorescu D, Ushio-Fukai M. NAD(P)H oxidase: role in cardiovascular biology and disease. Circ Res 2000; 86: 494501.

[19] Ohtsu H, Frank GD, Utsunomiya H, Eguchi S. Redox-dependent protein kinase regulation by angiotensin II: mechanistic insights and its pathophysiology. Antioxid Redox Signal 2005; 7: 1315-26.

[20] Pueyo ME, Gonzalez W, Nicoletti A, Savoie F, Arnal JF, Michel JB. Angiotensin II stimulates endothelial vascular cell adhesion molecule-1 via nuclear factor-kappaB activation induced by intracellular oxidative stress. Arterioscler Thromb Vasc Biol 2000; 20: 645-51.

[21] Ferrario CM. Role of angiotensin II in cardiovascular disease therapeutic implications of more than a century of research. J Renin Angiotensin Aldosterone Syst 2006; 7: 3-14.

[22] Go AS, Chertow GM, Fan D, McCulloch CE, Hsu CY. Chronic kidney disease and the risks of death, cardiovascular events, and hospitalization. N Engl J Med 2004; 351: 1296-305.
[23] de Vinuesa SG, Goicoechea M, Kanter J, et al. Insulin resistance, inflammatory biomarkers, and adipokines in patients with chronic kidney disease: effects of angiotensin II blockade. J Am Soc Nephrol 2006; 17: S206-S212.

[24] Weir MR. Effects of renin-angiotensin system inhibition on endorgan protection: can we do better? Clin Ther 2007; 29: 1803-24.

[25] Lewis EJ, Hunsicker LG, Bain RP, Rohde RD. The effect of angiotensin-converting-enzyme inhibition on diabetic nephropathy. The Collaborative Study Group. N Engl J Med 1993; 329: 1456-62.

[26] Brenner BM, Cooper ME, de Zeeuw D, et al. Effects of losartan on renal and cardiovascular outcomes in patients with type 2 diabetes and nephropathy. N Engl J Med 2001; 345: 861-9.

[27] Casas JP, Chua W, Loukogeorgakis S, et al. Effect of inhibitors of the renin-angiotensin system and other antihypertensive drugs on renal outcomes: systematic review and meta-analysis. Lancet 2005; 366: 2026-33.

[28] Timmermans PB, Wong PC, Chiu AT, et al. Angiotensin II receptors and angiotensin II receptor antagonists. Pharmacol Rev 1993; 45: $205-51$.

[29] Inagami T, Guo DF, Kitami Y. Molecular biology of angiotensin II receptors: an overview. J Hypertens Suppl 1994; 12: S83-S94.

[30] Balmforth AJ, Bryson SE, Aylett AJ, et al. Comparative pharmacology of recombinant rat AT1A, AT1B and human AT1 receptors expressed by transfected COS-M6 cells. Br J Pharmacol 1994; 112 : 277-81.

[31] Griendling KK, Lassegue B, Alexander RW. Angiotensin receptors and their therapeutic implications. Annu Rev Pharmacol Toxicol 1996; 36: 281-306.

[32] Chen X, Li W, Yoshida H, et al. Targeting deletion of angiotensin type 1B receptor gene in the mouse. Am J Physiol 1997; 272: F299-F304.

[33] Ichiki T, Labosky PA, Shiota C, et al. Effects on blood pressure and exploratory behaviour of mice lacking angiotensin II type-2 receptor. Nature 1995; 377: 748-50.

[34] Bedecs K, Elbaz N, Sutren M, et al. Angiotensin II type 2 receptors mediate inhibition of mitogen-activated protein kinase cascade and functional activation of SHP-1 tyrosine phosphatase. Biochem J 1997; 325: 449-54.

[35] Ushio-Fukai M, Griendling KK, Akers M, Lyons PR, Alexander RW. Temporal dispersion of activation of phospholipase C-beta1 and -gamma isoforms by angiotensin II in vascular smooth muscle cells. Role of alphaq/11, alpha12, and beta gamma $\mathrm{G}$ protein subunits. J Biol Chem 1998; 273: 19772-7.

[36] Ushio-Fukai M, Alexander RW, Akers M, Lyons PR, Lassegue B, Griendling KK. Angiotensin II receptor coupling to phospholipase $\mathrm{D}$ is mediated by the betagamma subunits of heterotrimeric $\mathrm{G}$ proteins in vascular smooth muscle cells. Mol Pharmacol 1999; 55: 142-9.

[37] Berridge MJ, Dupont G. Spatial and temporal signalling by calcium. Curr Opin Cell Biol 1994; 6: 267-74.

[38] Vallega GA, Canessa ML, Berk BC, Brock TA, Alexander RW. Vascular smooth muscle $\mathrm{Na}^{+}-\mathrm{H}^{+}$exchanger kinetics and its activation by angiotensin II. Am J Physiol 1988; 254: C751-758.

[39] D'Angelo G, Graceffa P, Wang CA, Wrangle J, Adam LP. Mammal-specific, ERK-dependent, caldesmon phosphorylation in smooth muscle. Quantitation using novel anti-phosphopeptide antibodies. J Biol Chem 1999; 274: 30115-21.

[40] D'Angelo G, Adam LP. Inhibition of ERK attenuates force development by lowering myosin light chain phosphorylation. Am J Physiol Heart Circ Physiol 2002; 282: H602-H610.

[41] Webb RC. Smooth muscle contraction and relaxation. Adv Physiol Educ 2003; 27: 201-6.

[42] Wetzker R, Bohmer FD. Transactivation joins multiple tracks to the ERK/MAPK cascade. Nat Rev Mol Cell Biol 2003; 4: 651-7.

[43] Eguchi S, Matsumoto T, Motley ED, Utsunomiya H, Inagami $\mathrm{T}$. Identification of an essential signaling cascade for mitogenactivated protein kinase activation by angiotensin II in cultured rat vascular smooth muscle cells. Possible requirement of Gq-mediated p21ras activation coupled to a $\mathrm{Ca}^{2+} /$ calmodulin-sensitive tyrosine kinase. J Biol Chem 1996; 271: 14169-75.

[44] Navar LG, Harrison-Bernard LM, Wang CT, Cervenka L, Mitchell KD. Concentrations and actions of intraluminal angiotensin II. J Am Soc Nephrol 1999; 10 (Suppl 11): S189-S195.

[45] Carey RM, Siragy HM. Newly recognized components of the renin-angiotensin system: potential roles in cardiovascular and renal regulation. Endocr Rev 2003; 24: 261-71. 
[46] Zhou Y, Boron WF. Role of endogenously secreted angiotensin II in the $\mathrm{CO}_{2}$-induced stimulation of $\mathrm{HCO}_{3}$ reabsorption by renal proximal tubules. Am J Physiol Renal Physiol 2008; 294: F245F252.

[47] Liu FY, Cogan MG. Angiotensin II stimulates early proximal bicarbonate absorption in the rat by decreasing cyclic adenosine monophosphate. J Clin Invest 1989; 84: 83-91.

[48] Houillier P, Chambrey R, Achard JM, Froissart M, Poggioli J, Paillard M. Signaling pathways in the biphasic effect of angiotensin II on apical $\mathrm{Na} / \mathrm{H}$ antiport activity in proximal tubule. Kidney Int 1996; 50: 1496-1505.

[49] Han HJ, Park SH, Koh HJ, Taub M. Mechanism of regulation of $\mathrm{Na}^{+}$transport by angiotensin II in primary renal cells. Kidney Int 2000; 57: 2457-67.

[50] Harwalkar S, Chang CH, Dulin NO, Douglas JG. Role of phospholipase A2 isozymes in agonist-mediated signaling in proximal tubular epithelium. Hypertension 1998; 31: 809-14.

[51] Haithcock D, Jiao H, Cui XL, Hopfer U, Douglas JG. Renal proximal tubular AT2 receptor: signaling and transport. J Am Soc Nephrol 1999; 10 (Suppl 11): S69-S74.

[52] Horita S, Zheng Y, Hara C, et al. Biphasic regulation of $\mathrm{Na}^{+}-\mathrm{HCO}_{3}{ }^{-}$ cotransporter by angiotensin II type $1 \mathrm{~A}$ receptor. Hypertension 2002; 40: 707-12.

[53] Zheng Y, Horita S, Hara C, et al. Biphasic regulation of renal proximal bicarbonate absorption by luminal $\mathrm{AT}_{1 \mathrm{~A}}$ receptor. $\mathrm{J} \mathrm{Am}$ Soc Nephrol 2003; 14: 1116-22.

[54] Grone HJ, Simon M, Fuchs E. Autoradiographic characterization of angiotensin receptor subtypes in fetal and adult human kidney. Am J Physiol 1992; 262: F326-F331.

[55] Allen AM, Zhuo J, Mendelsohn FA. Localization of angiotensin AT1 and AT2 receptors. J Am Soc Nephrol 1999; 10 (Suppl 11): S23-S29.

[56] Alper SL. Genetic diseases of acid-base transporters. Annu Rev Physiol 2002; 64: 899-923.

[57] Soleimani M, Burnham CE. Physiologic and molecular aspects of the $\mathrm{Na}^{+}: \mathrm{HCO}_{3}{ }^{-}$cotransporter in health and disease processes. Kidney Int 2000; 57: 371-84.

[58] Geibel J, Giebisch G, Boron WF. Angiotensin II stimulates both $\mathrm{Na}^{+}-\mathrm{H}^{+}$exchange and $\mathrm{Na}^{+} / \mathrm{HCO}_{3}{ }^{-}$cotransport in the rabbit proximal tubule. Proc Natl Acad Sci USA 1990; 87: 7917-20.

[59] Coppola S, Fromter E. An electrophysiological study of angiotensin II regulation of $\mathrm{Na}-\mathrm{HCO}_{3}$ cotransport and $\mathrm{K}$ conductance in renal proximal tubules. I. Effect of picomolar concentrations. Pflugers Arch 1994; 427: 143-50.

[60] Tsuganezawa H, Sato S, Yamaji Y, Preisig PA, Moe OW, Alpern RJ. Role of c-SRC and ERK in acid-induced activation of NHE3. Kidney Int 2002; 62: 41-50.

[61] Espiritu DJ, Bernardo AA, Robey RB, Arruda JA. A central role for Pyk2-Src interaction in coupling diverse stimuli to increased epithelial NBC activity. Am J Physiol Renal Physiol 2002; 283: F663-F670.

[62] Dulin NO, Alexander LD, Harwalkar S, Falck JR, Douglas JG. Phospholipase A2-mediated activation of mitogen-activated protein kinase by angiotensin II. Proc Natl Acad Sci USA 1998; 95: 8098102.

[63] Hirabayashi T, Murayama T, Shimizu T. Regulatory mechanism and physiological role of cytosolic phospholipase A2. Biol Pharm Bull 2004; 27: 1168-73.
[64] Endou H. Distribution and some characteristics of cytochrome P450 in the kidney. J Toxicol Sci 1983; 8: 165-76.

[65] Romero MF, Madhun ZT, Hopfer U, Douglas JG. An epoxygenase metabolite of arachidonic acid 5,6 epoxy-eicosatrienoic acid mediates angiotensin-induced natriuresis in proximal tubular epithelium. Adv Prostaglandin Thromboxane Leukot Res 1991; 21A: 205-8.

[66] Kauser K, Clark JE, Masters BS, et al. Inhibitors of cytochrome P450 attenuate the myogenic response of dog renal arcuate arteries. Circ Res 1991; 68: 1154-63.

[67] Harder DR, Gebremedhin D, Narayanan J, et al. Formation and action of a P-450 4A metabolite of arachidonic acid in cat cerebral microvessels. Am J Physiol 1994; 266: H2098-H2107.

[68] Roman RJ. P-450 metabolites of arachidonic acid in the control of cardiovascular function. Physiol Rev 2002; 82: 131-85.

[69] Capdevila JH, Falck JR, Harris RC. Cytochrome P450 and arachidonic acid bioactivation. Molecular and functional properties of the arachidonate monooxygenase. J Lipid Res 2000; 41: 163-81.

[70] Spector AA, Norris AW. Action of epoxyeicosatrienoic acids on cellular function. Am J Physiol Cell Physiol 2007; 292: C996C1012.

[71] Muller DN, Theuer J, Shagdarsuren E, et al. A peroxisome proliferator-activated receptor-alpha activator induces renal CYP2C23 activity and protects from angiotensin II-induced renal injury. Am J Pathol 2004; 164: 521-32.

[72] Min LJ, Mogi M, Li JM, Iwanami J, Iwai M, Horiuchi M. Aldosterone and angiotensin II synergistically induce mitogenic response in vascular smooth muscle cells. Circ Res 2005; 97: 434-42.

[73] Chai W, Garrelds IM, de Vries R, Batenburg WW, van Kats JP, Danser AH. Nongenomic effects of aldosterone in the human heart: interaction with angiotensin II. Hypertension 2005; 46: 701-6.

[74] Kambara A, Holycross BJ, Wung P, et al. Combined effects of low-dose oral spironolactone and captopril therapy in a rat model of spontaneous hypertension and heart failure. J Cardiovasc Pharmacol 2003; 41: 830-7.

[75] Hall A. Small GTP-binding proteins and the regulation of the actin cytoskeleton. Annu Rev Cell Biol 1994; 10: 31-54.

[76] Aikawa R, Komuro I, Yamazaki T, et al. Rho family small G proteins play critical roles in mechanical stress-induced hypertrophic responses in cardiac myocytes. Circ Res 1999; 84: 458-66.

[77] Matrougui K, Tanko LB, Loufrani L, et al. Involvement of Rhokinase and the actin filament network in angiotensin II-induced contraction and extracellular signal-regulated kinase activity in intact rat mesenteric resistance arteries. Arterioscler Thromb Vasc Biol 2001; 21: 1288-93.

[78] Holla VR, Adas F, Imig JD, et al. Alterations in the regulation of androgen-sensitive Cyp 4a monooxygenases cause hypertension. Proc Natl Acad Sci U S A 2001; 98: 5211-6.

[79] Gainer JV, Bellamine A, Dawson EP, et al. Functional variant of CYP4A11 20-hydroxyeicosatetraenoic acid synthase is associated with essential hypertension. Circulation 2005; 111: 63-9.

[80] Nakagawa K, Holla VR, Wei Y, et al. Salt-sensitive hypertension is associated with dysfunctional Cyp4a10 gene and kidney epithelial sodium channel. J Clin Invest 2006; 116: 1696-1702.

[81] Imig JD. Epoxide hydrolase and epoxygenase metabolites as therapeutic targets for renal diseases. Am J Physiol Renal Physiol 2005; 289: F496-F503. 